Ryszard Koziołek (D) https://orcid.org/0000-0002-8845-233X

Uniwersytet Śląski

ryszard.koziolek@us.edu.pl

\title{
Przedwczesne informacje o śmierci powieści
}

\section{The Premature News of the Novel's Death}

1. Co sądzi Pan o skonstruowanej przez Thomasa Pavla historii powieści? Czy źródłowy pomysł, by tworzyć ją na podstawie dychotomii zapisanego w niej ideału życia/ jego karykatury, jest przekonujący? Jakie są zalety, a jakie wady tego konceptu?

Zaletą jest niewątpliwie możliwość nowej syntezy dziejów powieści, czyli stworzenie symulacyjnego modelu rozwoju gatunku, który w ujęciu Pavla opiera się na fundamencie zmiennej korelacji między ideałami moralnymi bohaterów a środowiskiem społeczno-historycznym, które tych ideałów nie podziela. Ujęcie Pavla eksponuje wpływową rolę powieści jako składnika „genealogii moralności" (w Nietzscheańskim rozumieniu). Atrakcyjna klarowność ujęcia Pavla wynika jednak z istotnej redukcji problematyki konkretnych powieści, a nawet jej historycznych odmian gatunkowych, w których inne aspekty przedstawienia miały znaczenie równie istotne, co ideowe napięcie między bohaterem a światem. Zwracał na to uwagę Milan Kundera, traktując powieść jako eksperymentowanie (za pomocą postaci) na wielkich tematach egzystencjalnych. W koncepcji Pavla pewnej redukcji ulega heteronomia głosów powieściowych (narratora, postaci, podmiotów nieludzkich), dzięki którym bohater i czytelnik konfrontują się z innymi niż własne sądami, miejscami, ideami, formami wypowiedzi etc. Ta wielość służy ostatecznie upodmiotowieniu czytelników lub choćby tylko uświadomieniu sobie przez nich, kim są, ale często, co może ważniejsze, narusza lub rozbija fałszywą tożsamość ukształtowaną wyłącznie w obrębie znanej kultury rodzimej.

2. Czy tak pomyślana historia - „żywoty powieści” (jak głosi tytuł monografii Pavla, która jest rozwinięciem intuicji wyrażonych w eseju Powieść w poszukiwaniu samej siebie: morfologia historyczna) - wnosi wiedzę na temat źródeł nowoczesnej podmiotowości (w rozumieniu Charlesa Taylora)? Czy 
zaproponowana przez Pavla perspektywa ujawnia transformacje „tła” samorozumienia w ciągu stuleci? Czy ma jakiś związek z „narracją odczarowania”? Taka była teza klasycznej pracy Iana Watta: Narodziny powieści (1957). Badacz opisywał związki między indywidualizacją bohaterów w powieściach Daniela Defoe, Henry'ego Fieldinga czy Samuela Richardsona a przemianami społeczeństwa nowożytnego pod wpływem protestanckiego kapitalizmu i gwałtownego uprzemysłowienia. Kwestia ukazania walki bohaterów o własną podmiotowość wydaje się również kluczowym składnikiem koncepcji Pavla. Warto dodać do tego również upodmiotowienie czytelnika powieści. Wobec rosnącego lekceważenia (zwłaszcza w nowoczesnym modelu kształcenia) poznawczych korzyści z czytania powieści ich rola w kulturze zachodniej edukacji wynika przede wszystkim z tego, że zapewniają trwanie humanistyki w życiu dorosłego człowieka już po ustaniu obowiązku szkolnego. Inaczej mówiąc, obcowanie z fikcją literacką sprawia, że „wielkie tematy egzystencjalne” oraz rozmaite formy wypowiedzi literackiej stają się trwałym składnikiem doświadczenia kulturowego człowieka nowoczesnego, niezwiązanego zawodowo z instytucjami literatury. Głównym doświadczeniem człowieka nowoczesnego są niefortunne próby opanowania wielości przejawów zagęszczonego informacyjnie i materialnie świata. Choć bohaterowie powieści od Defoe do Fiodora Dostojewskiego, Marcela Prousta czy Jamesa Joyce'a nie radzą sobie z tym, to jednak dla czytelnika czytanie o ich zmaganiach jest swoistym treningiem obcowania z taka wielością. W losach bohaterów ćwiczy on alternatywne scenariusze własnego życia - opracowane estetycznie i etycznie w sposób, który czyni jej atrakcyjnymi i pożytecznymi jako wzorce lub przestrogi życiowe. Czytanie powieści było do czasu wynalezienia kina jedynym powszechnym sposobem wyobrażania sobie możliwości życia w innym czasie i innej przestrzeni.

„Narracja odczarowania” jest nieodłącznie wpisana w klasyczne narracje Zachodu, na długo przed właściwą nowoczesnością. Zakończenie legendy o Tristanie i Izoldzie, Don Kichota czy Pani Bovary przynosi w każdym wypadku rozpoznanie nieprzyległości ideału i życia, co jednak w oczach czytelnika nie odbiera wartości marzeniom bohaterów. Niemniej dopiero nowoczesność zobiektywizowała „świat” w amoralny i obojętny kompleks praw naturalnych i społecznych lub niemożliwy do ogarnięcia w żadnej narracji chaos zjawisk. Konfrontacja ideałów bohatera z takim światem wyznacza główną oś rozwojową także w powieści nowoczesnej. Bohaterowie Illusions perdu Honoré de Balzaca i $A$ la recherche du temps perdu Prousta doświadczają rosnącej alienacji w świecie, który na pozór jest ich własny (rodziny, miasta, klasy, społeczeństwa), a jedynym fortunnym aktem scalającym jest o-powieść o tym.

3. Co myśli Pan o tego rodzaju „etyce czytania” jako narzędziu służącym artykulacji źródeł moralnych (moralnych w sensie pojemniejszym, bo związanym nie tyle z zestawem norm i powinności, ile raczej z kwestiami „dobrego życia”), których ślady są rozpoznawane w powieściach? 
Określenie Frederica Jamesona, że powieść to „maszyna do życia w pewnym określonym rodzaju czasowości” wydaje się dobrze ujmować także aspekt etyczny czytania powieści. Mam na myśli zarówno korzystanie z niej jako symulacyjnej maszyny afektywno-poznawczej, pozwalającej przeżywać nie-swoje problemy egzystencjalne, społeczne, historyczne czy moralne, jak i użyteczność reprezentacji powieściowych $\mathrm{w}$ inscenizowaniu skomplikowanych zagadnień wszelkich odmian; zwłaszcza nadawanie abstrakcyjnym kwestiom filozoficznym czy moralnym kształtów personalnych i fabularnych. Dzięki ich atrakcyjności w zakresie przedstawienia i formy opowiadania skomplikowane bądź obce czytelnikowi zagadnienia stają się - niejako mimochodem, przy okazji czytania - przedmiotem rozważań jego zaangażowanej świadomości. Dokonujemy przy tym złożonych operacji poznawczych i aksjologicznych, które ulepszają nasze kompetencje kulturowe i zwiększają nasz kapitał komunikacyjny, jeśli chodzi o zdolność artykulacji naszych afektów i poglądów. Dotyczy to zwłaszcza powieści nowoczesnej, która koncentruje się na wydarzeniach codziennych i losach zwykłych ludzi.

4. Czy pojawiają się w tej historycznoliterackiej narracji elementy, które Pana zdaniem warto by mocniej wyeksponować lub, przeciwnie, zmarginalizować, osłabić ich rolę? Może zaproponowana w artykule historia powieści zawiera jakąś istotną lukę?

Przy całej atrakcyjności i elegancji modelu Pavla nie sposób zapomnieć o innych elementach organizujących ewolucję gatunku. Myślę o ewolucji form dialogowych, o przemianach narratora, o roli metafikcji, o powieści-encyklopedii. $\mathrm{Z}$ innej strony, czyli za sprawą prac Michaiła Bachtina, widzimy powieść jako bezkresny pojemnik na gatunki, a może na wszelkie formy wypowiedzi, nie tylko literackie, które powieść bez trudu absorbuje. Opisu narodzin i ewolucji tej właściwości gatunku nie znajdujemy u Pavla.

5. Jak projektowana przez Pavla wizja „długiego trwania powieści” przedstawia się na tle modeli historii powieści tworzonych przez innych badaczy (na przykład przez Györgya Lukácsa)?

Wydaje się, że najbliżej mu do innego modelu binarnego, który oparty był na opozycji eposu i powieści, co analizowali nie tylko Lukács, ale także Michaił Bachtin, Eric Auerbach czy Franco Moretti. Chodzi generalnie o transformację gatunku, która przebiega od eposu jako przedstawienia kompletnego świata $\mathrm{z}$ jego podmiotem zbiorowym, jednorodnym czasem, pewnością co do znaczenia prezentowanych wydarzeń do powieści nowoczesnej, która podejmuje maksymalistyczne zamierzenia eposu w zakresie skali przedstawienia, ale nie wyjawia sensu tych zdarzeń. W poszukiwaniu straconego czasu czy Ulisses manifestują niemożliwość sprostania w narracji złożoności opisywanych światów. Owocuje to nową kondycją bohatera, wyalienowanego z na pozór znanego sobie środowiska oraz wyrażającego przekonanie o kryzysie lub zbliżającym się upadku znanego sobie świata. 
6. Opisując przygody nowożytnej powieści europejskiej, Pavel obraca się głównie w kręgu powieści francuskiej, niemieckiej, angielskiej i amerykańskiej, rosyjskiej oraz hiszpańskiej. Czy kategorie wykuwane dla potrzeb tego opisu wykazują operatywność wobec historii polskiej powieści? Jak mogłaby wyglądać próba wpisania doświadczeń polskiej powieści w narrację Pavla? Jakie byłyby rezultaty takiej próby?

„Metoda ideograficzna” Pavla bardzo dobrze sprawdzi się w próbie syntezy dziejów powieści polskiej, z pewną jednakże modyfikacją. Historia polskiej powieści zaczyna się od XVIII wieku i prawie przez dwa wieki biegnie równolegle z katastrofą rozbiorów. Co oznacza, że w modelu binarnym - ideał jednostkowy vs. wroga mu rzeczywistość - pojawia się trzeci parametr: ideał powinności wobec podbitej ojczyzny. Daje to w rezultacie interesującą niespójność polegającą na przykład na trwaniu ideałów rycerskich w dobie triumfu etyki mieszczańskiej. Stąd swoiste pęknięcia w realizmie powieści Elizy Orzeszkowej, Henryka Sienkiewicza i Bolesława Prusa, których bohaterowie nie tylko walczą z twardą rzeczywistością materialnego świata, ale także usiłują sprostać moralnym i patriotycznym żądaniom niewidzialnej, bo nieprzedstawionej w powieściach historii najnowszej. W konsekwencji polska powieść nowoczesna opowiada o podwójnej porażce bohatera w próbie sprostania ideałom: nie sposób wypełnić żądania poświęcenia się walce za ojczyznę w sytuacji, kiedy nie ma ona żadnych szans powodzenia, jak również nie można ocalić ideału miłosnego i „pięknej duszy” w świecie całkowicie zmaterializowanym. Najdoskonalszym przedstawieniem takiej podwójnej porażki jest oczywiście Lalka.

7. Tekst Pavla kończy się wyznaniem wiary w żywotność powieści jako (zmieniającej się, lecz zachowującej skomplikowaną ciągłość w czasie) formy wyrażającej ludzkie doświadczenie. Nie jest to teza przyjmowana obecnie w sposób powszechny i bezdyskusyjny, przeciwnie, słyszalne są (i nie od dziś) głosy mówiące o „śmierci”, „końcu” czy „abdykacji” powieści (między innymi ze względu na dominującą rolę nowych mediów elektronicznych, kres „ery Guttenberga” etc.). Jakie jest Pana stanowisko w tej kwestii, czy formuła Pavla („Zarówno najstarsze tradycje literackie, jak i te, które się dopiero rodzą, wybierają powieść jako sposób na potwierdzenie swej nowoczesności”) jest dla Pana przekonująca?

Zdecydowanie przedwczesne okazały się informacje o śmierci powieści. Choć nie oczekujemy już od tego gatunku ciąłego dostarczania nam „nowości” czy też „o-po-wieści” o światach, których czytelnik nie może odwiedzić, to jego ranga narracyjna nie maleje. Wobec nieprawdopodobnego mnożenia się informacji, „newsów”, narracji efemerycznych: o skandalach, wynalazkach, podróżach, intrygach, wojnach, romansach itp. powieść pozostaje ciągle niezastąpioną formą narracyjnej i fabularnej integracji tego żywiołu. Nie potrafi sprostać mimetycznej atrakcyjności, jaką daje widzowi wysoka technologia obrazu; nie ma też dostępu do informacji, jaki mają agencje informacyjne. A jednak 
jej spory rozmiar, operowanie rozbudowanym przedstawieniem słownym, dostosowywanie się do wciąż nowych tematów i form mowy potocznej oraz zdolność wytwarzania afektywnego zaangażowania czytelnika w treść opowieści czyni powieść bezkonkurencyjną wobec wszystkich innych gatunków literackich. Różniąca się tak mocno w swoich antycznych początkach, odrębna i nieznająca siebie w językowych i kulturowych odmianach przednowoczesnych zlała się w całość w „złotym” XIX wieku - wówczas zaczęła się trwająca do dziś planetarna kariera gatunku. Obecnie powieść jest powszechnie akceptowana w każdym niemal kręgu kulturowym już nie tyle jako gatunek, ile jako technologia fikcji narracyjnej, która napędza komiks, kino, gry wideo, seriale telewizyjne, pozostając ciągle tym, czym jest od wieków - literaturą. 